\title{
АНГЛИЙСКИЙ РЕЧЕВОЙ ЭТИКЕТ
}

\section{Галибердова Д.Р.}

Ставропольский филиал Московского

Педагогического Государственного Университета, г. Ставрополь, Ставропольский край, Российская Федерация

В статье рассматриваются проблемы, возникающие при незнании норм речевого этикета. Незнание речевого этикета может повлечь за собой общественное порицание или даже привести к конфликту. Для того, чтобы избежать этого, необходимо владеть нормами речевого этикета. А для тех, кто изучает английский, эта тема особенно актуальна ввиду некоторых различий норм обрашения в русском и английском языках.

Ключевые слова: этикет; речевой этикет; форма обращения; нормы общения.

\section{ENGLISH SPEECH ETIQUETTE}

\section{Galiberdova D.R.}

Stavropol branch of Moscow Pedagogical State University, Stavropol, Stavropol region, Russian Federation

Nowadays, speech etiquette receives more and more frequent spread in certain circles, which reflects the experience, moral concepts, as well as the tastes of certain social groups. Ignorance of speech etiquette can lead to public criticism, or even lead to conflict. To avoid this, you must own norms of speech etiquette. And for those who learn English, this issue is particularly relevant in view of certain differences in treatment standards in the Russian and English languages.

Keywords: etiquette; speech etiquette; form of address; communication standards. 
Наверно нет такой языковой культуры, в которой не предъявлялись бы требования к нормам речевого этикета. Можно сказать, что речевой этикет имеет древнейшую историю. А что касается первобытного времени, то речевым этикетом представлялись ритуальные действа. Слово - не просто набор букв и звуков, в слове выражаются особые значения, связанные с магическим и обрядовым представлением, взаимоотношения людей и космической силы. И потому в речевой деятельности отражается влияние, как считали первобытные люди, на животных и окружающий мир.

Конечно же, с течением времени, происходит изменение речевого этикета и его места в современном обществе. Эти изменения связаны с мифологическими и религиозными верованиями, представлениями о незыблемых социальных иерархиях и проч.

Отчетливо видно, что в каждой нации можно выделить некие похожие традиции и устои. К примеру, наверно, в каждой нации существуют определенные формы приветствий и прощаний, уважительное обращение к старшим и т.п.

Речевой этикет предполагает соблюдение норм поведения и общения. Под речевым этикетом представляются разработанные правила речевого поведения, система речевых формул общения. Человек, владеющий речевым этикетом, приобретает авторитет, вызывает доверие и уважение. Владение нормами речевого этикета и, конечно же, их соблюдение, помогает человеку приобрести уверенность, непринужденность, человеку не приходится испытывать неловкость из-за незначительных нарушениях или неправильных действий, человек получает возможность избежать насмешки от окружающих.

Речевому этикету принадлежат определенные конструкции, например, конструкции выражения просьб; которые по-разному ориентируются на вежливость в общении, что в свою очередь, регулирует взаимодействие партнеров. В зависимости от ситуации выбирается конструкция обращений: в формальной и неформальной беседе, нейтральности обстановки, нарочито-вежливой или средней тональности, в беседах со знакомыми и незнакомыми людьми и т.п. И задача состоит в том, что выбрать в той или иной ситуации уместную 
форму обращения, что, в свою очередь, покажет уровень культуры и владения речевым этикетом.

Стоит отметить, что глубже всего, этикет изучался в лингвистике, где этикетом считается функционально-семантическая микросхема языковых единиц, которая привязана к стандартным ситуациям. Эти единицы социально заданы и национально-специфически, регулируют требования речевого поведения.

Наталья Леонидовна Соколова (автор монографии «Английский речевой этикет») определяет данное понятие, как «разветвлённую языковую микросистему, ситуативно обусловленных, тематически сопряженных, коммуникативно направленных единиц, взаимосвязанных и взаимозависимых в рамках диалогических единств в момент реального функционирования в речи»

Правила речевого этикета показывают, как общие, так и особые национально-специфические представления о вежливости, могут наложить запрет на недопустимые с точки зрения этики речевые обороты. Речевой этикет реализуется на различных языковых уровнях: лексическом и фразеологическом, грамматическом, стилистическом, интонационном, орфоэпическом, организационно-коммуникативном.

Знание речевого этикета важно не только для самих англичан, оно важно для всех изучающих английский, как иностранный. Английский речевой этикет своеобразен и имеет собственные правила и нормы, которые, однако, существенно расходятся с правилами и нормами, например, русского речевого этикета. Это может привести к тому, что даже очень культурный русский человек окажется невежливым среди англичан, если он, общаясь с ними на их языке, не владеет английским речевым этикетом. Точно так и английский джентльмен может показаться невежливым в общении на русском языке с культурными русскими, если он не изучал русский речевой этикет.

Перед тем, как ездить в Великобританию, следует сперва познакомиться с нормами поведения в английском обществе. Более доступным объектом для сравнения с привычными нам понятиями о нормах, является, в первую очередь, английский речевой этикет. К примеру, в России знакомятся фразой Очень приятно! А в ответ 
часто можно услышать Очень рад с вами познакомиться!, В Англии же, как правило, обмениваются репликой How do you do?, соответствующей русскому приветствию Здравствуйте!.

Существенно изменяется в английском языке и слово пожалуйста, в русском употреблении уместное почти в любой удобной и неудобной ситуации. Наверно только лишь в просьбе оно соответствует английскому выражению please. Подставить слово please в свою ответную реплику на чью-то благодарность, извинение и т. д. (по ассоциации с употреблением русского пожалуйста) - чревато самыми курьезными последствиями. В подобных ситуациях многозначность русского клише пожалуйста выражается целым рядом английских штампов: That's all right; Never mind; Don't mention it; line it is; Help yourself; Not at all; Certainly; Why not?, etc.

Отличительная черта национального английского мышления отсутствие прямых суждений, непосредственного выражения своего мнения. Например, вместо: Вы не правы или Я с вами не согласен, англичанин скажет: I am afraid, you are not quite right. Боюсь вы не совсем правы или: I am afraid, I cannot agree with you - Боюсь, я не могу с вами согласиться. Вместо того, чтобы сказать Вы лжете или Я вам не верю, англичанин предпочтет вежливое замечание: You have been very economical with the truth - Вы были очень экономны в правдивом изложении фактов. Если на континенте могут сказать: You are a liar, Sir, and rather a dirty one - Вы лжец, сэр, и довольно грязный, в Англии это будет звучать: Oh, is that so? - Неужели так бывает? или: That is rather an unusual story, isn't it? - Это довольно необычная история, не так ли?

Таким образом, основными ценностями английской культуры чаще всего называют индивидуализм, рационализм, независимость, прагматизм, соревновательность, равенство, традиционализм, толерантность. Данные характеристики играют важную роль, т.к. отображаются в образе жизни, межличностных отношениях и поведении англичан. Отличительная черта национального английского мышления - отсутствие прямых суждений, непосредственного выражения своего мнения, позитивное мышление. 
Но выражение неуважения или даже непочтения возможно и в английском обществе. Существуют даже специальные глаголы, означающие «оказывать неуважение к кому/чему-либо, высмеивая, презрительно усмехаясь»: sneer, scoff, jeer, gird, flout, gibe/jibe, fleer, taunt, twit, mock, ridicule, deride. Дифференциальные признаки этих слов - «злобно» (ridicule, deride, taunt, sneer), «жестоко» (twit), «оскорбительно» (scoff), «цинично, грубо» (sneer, jeer, gird), «злорадно» (taunt), «вопреки нормам поведения» (mock, taunt), «унижая» (ridicule), «громко» (jeer), «гримасничая» (fleer), «с кривой усмешкой» (sneer), «с презрительным смехом» (deride), «передразнивая» (mock, taunt, twit, gibe), «иногда добродушно» (gibe) (WNDS, SBED, LDCE, RHD).

Отрицательное отношение в виде формульного раскрытия можно проследить и в коротком, едком или недоверчивом вопросе. К примеру: "Mr. Starr has denied the allegation of his previous contact with the committee." - “Наs he?” Именно такая форма считается высшей степенью недоверия или выражения негативного отношения к собеседнику и его высказыванию. Но, конечно же, не стоит опускать и такие моменты, как интонация и индивидуальные особенности собеседников.

Но все же, было бы огромной ошибкой не показать и такую важную характеристику поведения в конфликтных ситуациях, в английском обществе, как перекладывание вины на себя. Данная характеристика проглядывается во фразе «It’s my fault». Виновность человека признается сразу же в общении. Это делается для того, чтобы собеседник великодушно признал и свою какую-нибудь вину. Тогда конфликтная ситуация сводится к соревнованию в благородстве. Это чисто английский стиль поведения.

Обобщая выше сказанное, можно надеяться, что владение нормами и приемами речевого этикета, участники общения избегут многие конфликтные ситуации, добьются взаимопонимания, заслужат уважительное отношение, не оскорбив, при этом, партнера. При общении речь собеседников должна следовать определенным правилам ведений разговоров, в противном случае собеседники не придут к 
консенсусу. Общение, обращение и поведение в целом должны следовать конкретным правилам той или иной социокультурной принадлежности. Можно добавить, что нормы речевого этикета являются неотъемлемой частью любой национальной культуры. Речевое поведение отражает традицию, жизненный опыт, мышление, менталитет и образ жизни любой нации.

\section{Список литературы}

1. Речевой этикет - [Электронный ресурс]. Режим доступа: https:// www.vspu.ru (дата обращения 20.12.2018)

2. Уровни вежливости в речи - [Электронный ресурс]. Режим доступа: https://knowledge.allbest.ru/ (дата обращения 7.02.2019)

3. Этикет как норма речи - [Электронный ресурс]. Режим доступа: http://lib2znate.ru (дата обращения 10.01.2019).

4. Особенности речевого этикета в странах изучаемого языка - [Электронный ресурс]. Режим доступа: https://www.bibliofond.ru/ (дата обращения 18.12.2018).

5. Овчинников В.В. Корни дуба. Впечатления и размышления об Англии и англичанах. «Издательство АСТ», 2005

\section{References}

1. Rechevoy etiket. https://www.vspu.ru/

2. Urovni vezhlivosti v rechi. https://knowledge.allbest.ru/

3. Etiket kak norma rechi. http://lib2znate.ru/

4. Osobennosti rechevogo etiketa v stranakh izuchaemogo yazyka. https:// www.bibliofond.ru/

5. Ovchinnikov V.V. Korni duba. Vpechatleniya i razmyshleniya ob Anglii i anglichanakh. «Izdatel'stvo AST», 2005. 